\title{
Demography of Priapism: Comparison between Sickle Cell and Non-Sickle Cell Disease Patients
}

\author{
Mohamed S. Al-Marhoon ${ }^{1, *}$, Mohamed S. Al-Masruri ${ }^{2}$ \\ ${ }^{1}$ Urology Division, Department of Surgery, Sultan Qaboos University, Sultanate of Oman \\ ${ }^{2}$ Urology Division, Department of Surgery, Sultan Qaboos University, Sultanate of Oman
}

*Corresponding Author: Dr. Mohamed S. Al-Marhoon, PhD, MD, MRCSEd, BSc, Senior Consultant Urological Surgeon,Urology Division, Department of Surgery, College of Medicine \& Health Sciences Sultan Qaboos University, Oman, Email: msalmarhoon@gmail.com

\begin{abstract}
Objectives: priapism is a relatively rare complication of sickle cell disease(SCD). In this study we aim to define the demography and risk factors for recurrent episodes of priapism in SCD and non-SCD patients. Methods: data on 28 males with priapism were retrospectively retrieved. The demographical, clinical, hematological, and biochemical parameters, management and its complications were studied. Comparison between SCD and non-SCD groups were done using statistical methods. Results: priapism patients were mostly adults (82\%), presented at a young age (26 years). SCD was the most important cause of priapism $(60.7 \%)$, painful erection $(78.6 \%)$ the most common presentation, with median frequency of priapism episodes significantly higher in SCD than non-SCD patients $(P=0.004)$. SCD patients had significantly lower mean of $\mathrm{Hb}(P=0.001)$ and higher mean of $W B C(P=0.011)$, platelets $(P=0.017), A L T(P=0.011)$, bilirubin $(P=0.003)$ and $L D H(P=0.027)$ than non-SCD patients. For medical therapy $50 \%$ had hydroxyurea and blood transfusion; while for surgical therapy $17.9 \%$ had distal penile shunt with a complications rate of $28.6 \%$ (7\% penile hematoma, $14.3 \%$ erectile dysfunction).As an outcome, $32 \%$ had detumescence, $14.3 \%$ persistent priapism, and 53.6\% recurrent priapism. Conclusion: sickle cell disease is the major risk factor for ischemic and stuttering priapism. Patients with SCD presented with priapism were young adults with low Hb, high WBC, platelets, bilirubin, ALT and LDH. These findings can be used to monitor priapism patients at presentation to predict those who are at risk of recurrent episodes to prevent the complications of pain and erectile dysfunction.
\end{abstract}

Keywords: Sickle cell disease, priapism, stuttering, risk factors, erectile dysfunction, Oman

\section{INTRODUCTION}

Priapism defined as a prolonged, persistent, and painful penile erection lasting for more than 4 hours without sexual stimulation. ${ }^{1}$ It is primarily caused by sickle cell disease (SCD), ${ }^{2}$ but other causes include: leukemia, myeloproliferative disorders, injury, side effect of specific medications (antihypertensives, antipsychotics, antidepressants, oral phosphodiesterase type 5 inhibitors, PDE5i), ${ }^{3,4}$ penile intracorporal injections, and rarely reported as a complication of dialysis in adult patients. ${ }^{5}$ However, the commonest causes of priapism in children are sickle cell disease (65\%), leukemia (10\%), trauma (10\%), idiopathic (10\%), and pharmacologicallyinduced (5\%). ${ }^{6}$

The incidence of priapism in the general population is estimated at 1.5 in 100,000 patients and 2.9 in 100,000 patients in males over 40 years of age. ${ }^{5}$ Priapism is classified into three main types: ischemic (low-flow), non-ischemic (high-flow) and recurrent ischemic (intermittent or stuttering). Ischemic priapism accounts for $95 \%$ of all cases and if lasting beyond four hours is similar to a compartment syndrome, characterized by the development of ischemia within the closed space of the corpora cavernosa, which severely compromises cavernous circulation. Hence it is a medical emergency that requires intervention to minimize irreversible consequences, such as smooth muscle necrosis, corporal fibrosis and the development of permanent erectile dysfunction. $^{7}$

Sickle cell disease is a genetic disorder of the b-globin gene. The defect in the gene 
manifests by replacement of glutamic acid by valine at the sixth position of the beta gene chain, with the consequences of making abnormal erythrocytes that are less deformable and sickled. ${ }^{8}$ Sickle cell diseasewas found to beprevalent in Oman (5.8\%). ${ }^{9}$ Priapism in SCD presents as acute episodes or stuttering priapism. The recurrent episodes of prolonged erections that last from a few minutes to three hours is defined as stuttering priapism. These repetitive vaso-occlusion can lead to erectile dysfunction. Evidence has shown that priapism results fromdeficient erection control mechanisms at a molecular level with abnormal signaling of the endothelium-derived nitric oxide andphosphodiesterase type 5 (PDE5) signal transduction pathway inthe penis. ${ }^{10}$ Interventions for priapism fall into two categories of preventing or reducing the frequency of priapic attacks, and treatingfulminant priapic episodes. Several treatments have been suggested including: analgesia; hydration; blood alkalinisation; red blood cell transfusion; partial exchange transfusion to lower hemoglobin $\mathrm{S}$; pharmaceutical agents; and surgical procedures ranging from aspiration to surgical shunts and even penile implantation for intractable cases. ${ }^{11}$

As priapism is a rare disease, in this study we aim to define the demography of priapism in Oman in sickle cell disease (SCD) and nonsickle cell disease (Non-SCD) patients. We will study the modes of treatments they have received and determine the factors that influence the occurrence of recurrent episodes of priapism. This will enable us to monitor this group of patients closely and manage them early to prevent the consequence of suffering from pain and the permanent erectile dysfunction.

\section{METHODS}

\subsection{Data Collection}

Data on consecutive patients with priapism were obtained retrospectively between July 2007 and December 2019through the electronic medical records of Sultan Qaboos University Hospital. The study was approved by the local institutional medical research and ethics committee. The following data were collected: age at first presentation, region, cause or risk factors, comorbidities, clinical presentation, biochemical markers, outcomeof treatment, complications, medical therapy, surgical therapy, episodes of priapism, hospital stay, and follow up.

\subsection{Procedures}

The medical treatments included: a) specific measures for sickle cell disease related priapism: intravenous hydration and parental narcotic analgesia, supplemental oxygen administration and alkalinisation with bicarbonate; b) blood transfusion as simple or exchange transfusion was given with the aim of increasing the tissue delivery of oxygen; c) hydroxyure: blocks the synthesis of deoxyribonucleic acid (DNA) by inhibiting ribonucleotide reductase, which has the effect of arresting cells in the S-phase with an established treatment for ameliorating SCD and improving patient life expectancy. ${ }^{12}$ The surgical treatments included: a) aspiration and irrigation with $0.9 \%$ saline solution in combination with intracavernous injection of phenylephrine $(\alpha-1$-adrenergic receptor $)$, which was prepared and used as described; ${ }^{13}$ b) percutaneous distal (corpora-glanular) shunt that aims to produce an outflow for ischemic blood from the corpora cavernosa thereby allowing the restoration of normal circulation within penile structures. The T-Shunt was used and details of the operative procedure as described. ${ }^{14}$

\subsection{Statistical Analysis}

Clinical, radiological and laboratory parameters of patients with SCD and non-SCD were presented using the descriptive statistical methods. Comparison between groups for symmetrical data were done using independent t-test, while for non-parametric data using Mann-Whitney U-test. Associations were tested by Pearson's correlation coefficient for continuous data and Chi-square for categorical data. Multinomial logistic regression used for the determination of variable effects on the study outcomes including: frequency of priapism episodes and treatment outcomes of priapism (detumescence, persistence, recurrence). The mean of continuous symmetrical data is presented as mean $\pm \mathrm{SD}$ (standard deviation), while for continuous asymmetrical data as median (range). The level of significance was setas $\mathrm{p}<0.05$. All data recording, statistical analysis, and results extractionwere achieved using the program of Statistical Package for the Social Sciences (IBM SPSS, USA, version 23). 


\section{ReSUlts}

This study recruited 28 patients with priapism with the mean age of $31.2 \pm 12.94$ years and age range of 3-74 years. There were 17.9 $(5 / 28)$ children and $82.1(23 / 28)$ adults. The mean age at first presentation was $26.1 \pm 13.36$ years (Figure 1). The overall number of priapism episodes were 4 (1-8).Most patients were from Muscat 35.7\% (10/28), Dakhilyyah $25.0 \%$ (7/28), Batinah $25.0 \%$ (7/28) and with $67.9 \%$ had no comorbidities like DM, HTN.Thelaboratory results were: Hemoglobin (Hb) $10.1 \pm 2.81 \mathrm{~g} / \mathrm{dL}$, White blood cells (WBC) $15.6 \pm 23.39 \times 10^{9} / \mathrm{L}$, Platelets $399.2 \pm$ $187.74 \times 10^{9} / \mathrm{L}$, Creatinine $62.1 \pm 18.27 \mathrm{umol} / \mathrm{L}$, Urea $3.4 \pm 1.23 \mathrm{mmol} / \mathrm{L}$, Potassium (K) $4.4 \pm$ $0.51 \mathrm{mmol} / \mathrm{L}, \quad$ Sodium $(\mathrm{Na}) \quad 140.3 \quad \pm$ $2.92 \mathrm{mmol} / \mathrm{L}$, Calcium (Ca) $2.2 \pm 0.10 \mathrm{mmol} / \mathrm{L}$, Lactate dehydrogenase (LDH)487.6 \pm 300.48IU/L, Aspartate transaminase (AST) $48.8 \pm 31.39 \mathrm{U} / \mathrm{L}$, Alanine transaminase(ALT) $50.0 \pm 50.29 \mathrm{U} / \mathrm{L}$, and Bilirubin53.9 \pm $48.83 \mathrm{umol} / \mathrm{mg}$. The urinalysis was normal in $92.9 \%$, urine culture normal in $89.3 \%$, penile blood gas analysis done in only $10.7 \%(3 / 28)$ patients and imaging done were: $10.7 \%(3 / 28)$ MRI, 7.1\% (2/28) Penile doppler US.

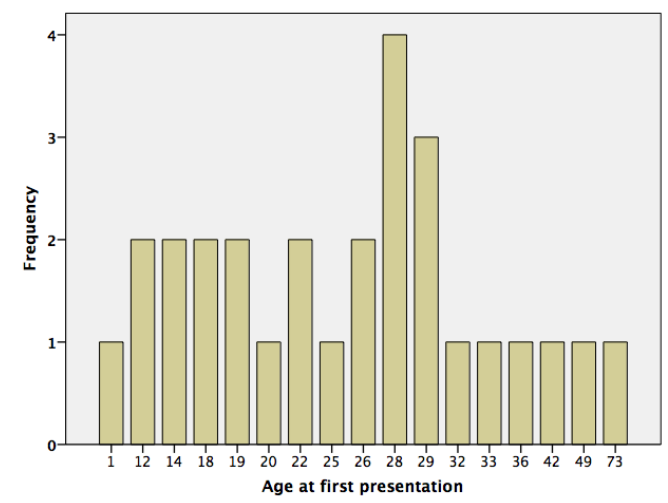

Figure 1. Age at first presentation

The most common presentation was painful erection $78.6 \%(22 / 28)$. Patients had medical therapy: $\quad 14.3 \%$ hydroxyurea, $50.0 \%$ hydroxyurea with blood transfusion; and surgical therapy: $53.6 \%$ had penile aspiration with phenylephrine injection, $17.9 \%$ had distal penile shunt. The complications rate was $28.6 \%(8 / 28)$ and included: $7 \%(2 / 28)$ penile hematoma, $14.3 \%(4 / 28)$ erectile dysfunction, 46.4\% (13/28) Asplenia and Cholecystectomy. The mean hospital was $4.9 \pm 6.53$ days and the mean follow upwas $3.4 \pm 3.61$ months. The clinical response (outcome) was as follows: $32.1 \%$ immediate detumescence, $14.3 \%$ persistent priapism, 53.6\% (15/28) recurrent priapism,(Figure 2).

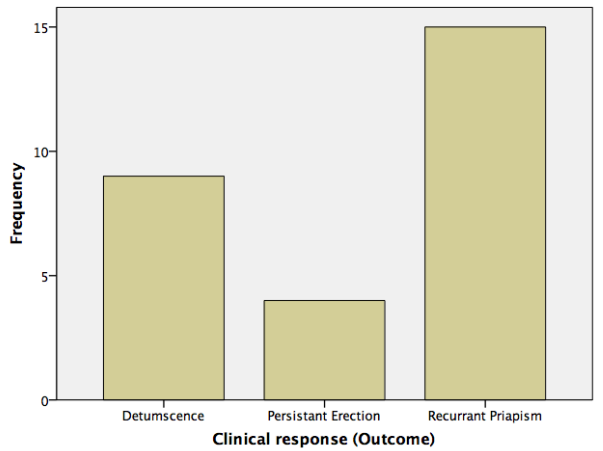

Figure 2. Clinical response (outcome)

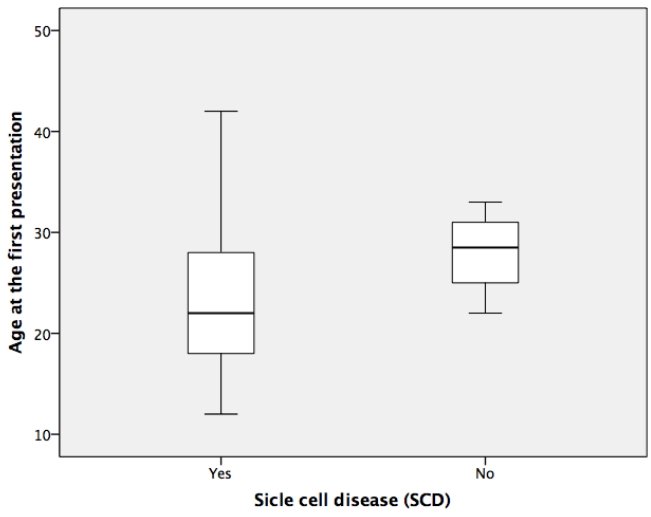

Figure 3. Age at first presentation grouped by SCD or non-SCD patients.

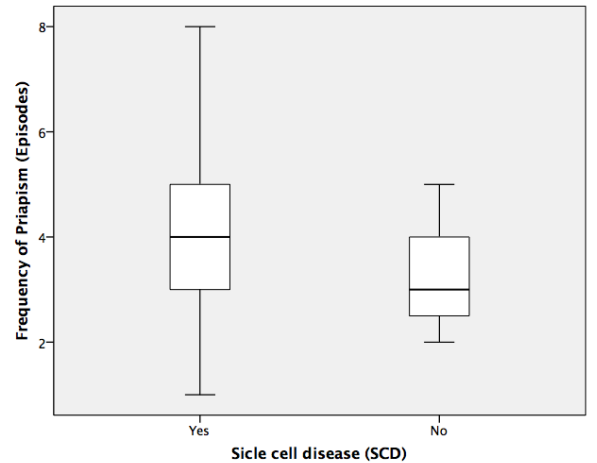

Figure 4. Frequency of priapism episodes in SCD patients

The comparison between the SCD and nonSCD priapism patients is presented (Table 1). The patients who had SCD as a risk factor constituted $60.7 \%$ (17/28) of the patients with priapism. Patients with SCD were younger at first presentation with priapism (Figure 3). All SCD patients had painful erections with the median frequency of priapism episodes being significantly higher in SCD than non-SCD patients $(\mathrm{P}=0.004)$ (Figure 4). Interestingly, all priapism patients from Dakhlyyah region were SCD (Figure 5). SCD patients had significantly lower mean of $\mathrm{Hb}$ than non-SCD, 
8.8 and $11.6(\mathrm{P}=0.001)$. in contrast, SCD patients had significantly higher mean of WBC $(\mathrm{P}=0.011)$, platelets $(\mathrm{P}=0.017)$, ALT $\quad(\mathrm{P}=$ $0.011)$, bilirubin $(\mathrm{P}=0.003)$ and $\mathrm{LDH}(\mathrm{P}=$ 0.027) than non-SCD patients. On the other hand, non-SCD patients had significantly higher mean of creatinine $(\mathrm{P}=0.047)$ and urea $(\mathrm{P}=.006)$ than SCD patients. The main medical treatment of SCD patients included combination of hydroxyurea\& exchange or simple blood transfusion. However, for the surgical treatment, SCD patients had more interventions in the form of aspiration \& phenylephrine intracavernosal injection and distal penile shunts $(\mathrm{P}=0.682)$. Complications were comparable in SCD and non-SCD patients (penile hematoma, erectile dysfunction and infertility) except for those related to SCD (asplenia and cholecystectomy). However, multinomial logistic regression did not show significant effect of the studied factors on the outcome of priapism.

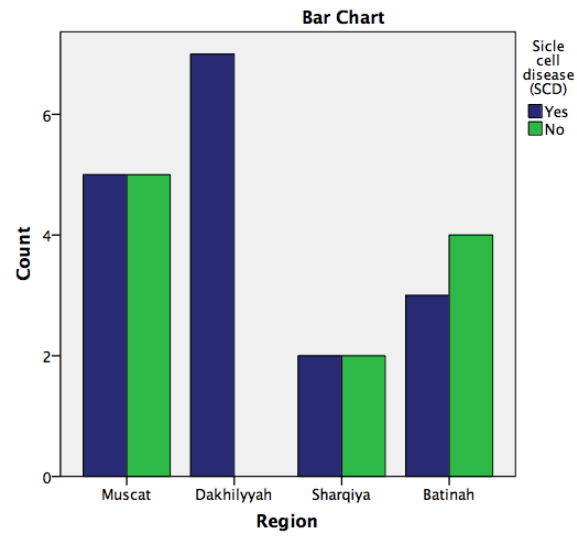

Figure 5. SCD patients by region

Table 1. Comparison between Sickle cell disease (SCD) and non-SCD priapism patients.

\begin{tabular}{|c|c|c|c|}
\hline & SCD & Non-SCD & P-value \\
\hline Number of patients & $17(60.7 \%)$ & $11(39.3)$ & \\
\hline $\begin{array}{l}\begin{array}{l}\text { Age at first presentation } \\
\text { (years) }\end{array} \\
\end{array}$ & $23.1 \pm 7.60$ & $28.0 \pm 4.55$ & 0.131 \\
\hline Region & & & 0.105 \\
\hline Muscat & 5 & 5 & \\
\hline Dakhilyyah & 7 & 0 & \\
\hline Sarqiya & 2 & 2 & \\
\hline Batinah & 3 & 4 & \\
\hline Risk factors (etiology) & & & 0.000 \\
\hline SCD & 17 & 0 & \\
\hline Thalassemia & 0 & 1 & \\
\hline Unknown & 0 & 10 & \\
\hline Comorbidities & & & 0.032 \\
\hline No & 15 & 4 & \\
\hline DM & 0 & 1 & \\
\hline HTN & 0 & 1 & \\
\hline Unknown & 2 & 5 & \\
\hline Presentation & & & 0.001 \\
\hline Painful erection & 17 & 5 & \\
\hline Non-painful erection & 0 & 6 & \\
\hline \multicolumn{4}{|l|}{ Biochemical markers } \\
\hline $\mathrm{Hbg} / \mathrm{dL}$ & $8.8 \pm 1.24$ & $11.6 \pm 2.07$ & 0.001 \\
\hline WBC $\times 10^{9} / \mathrm{L}$ & $13.2 \pm 3.02$ & $38.5 \pm 63.05$ & 0.011 \\
\hline Plateletsx $10^{9} / \mathrm{L}$ & $451.8 \pm 202.05$ & $431.5 \pm 173.94$ & 0.017 \\
\hline Bilirubin umol/mg & $73.6 \pm 47.59$ & $26.8 \pm 34.89$ & 0.003 \\
\hline ASTU/L & $55.5 \pm 24.60$ & $26.0 \pm 11.34$ & 0.142 \\
\hline ALTU/L & $63.65 \pm 57.52$ & $24.0 \pm 4.08$ & 0.014 \\
\hline Albumeng/dL & $43.77 \pm 4.45$ & $44.5 \pm 1.29$ & 0.439 \\
\hline LDHIU/L & $546.77 \pm 298.84$ & $236.0 \pm 146.24$ & 0.027 \\
\hline Creatinineumol/L & $56.8 \pm 14.37$ & $67.8 \pm 13.34$ & 0.047 \\
\hline Ureammol/L & $2.9 \pm 0.89$ & $4.3 \pm 1.76$ & 0.006 \\
\hline $\mathrm{Kmmol} / \mathrm{L}$ & $4.47 \pm 0.46$ & $4.2 \pm 0.33$ & 0.192 \\
\hline $\mathrm{Na} \mathrm{mmol} / \mathrm{L}$ & $139.65 \pm 1.90$ & $140.0 \pm 2.16$ & 0.113 \\
\hline Cammol/L & $2.24 \pm 0.11$ & $2.29 \pm 0.08$ & 0.819 \\
\hline Medical therapy & & & 0.000 \\
\hline
\end{tabular}


Demography of Priapism: Comparison between Sickle Cell and Non-Sickle Cell Disease Patients

\begin{tabular}{|c|c|c|c|}
\hline No treatment & 0 & 10 & \\
\hline Hydroxyurea & 4 & 0 & \\
\hline Hydroxyurea\& transfusion & 13 & 1 & \\
\hline Surgical therapy & & & 0.682 \\
\hline No intervention & 4 & 4 & \\
\hline $\begin{array}{l}\text { Aspiration \& Phenylephrine } \\
\text { intracavernosal injection }\end{array}$ & 10 & 5 & \\
\hline Distal penile shunt & 3 & 2 & \\
\hline Complications & & & 0.012 \\
\hline Penile hematoma & 1 & 1 & \\
\hline ED & 2 & 2 & \\
\hline Infertility & 1 & 0 & \\
\hline Aspelenia & 2 & 0 & \\
\hline Cholecystectomy & 11 & 2 & \\
\hline No & 0 & 7 & \\
\hline Hospital stay & $3(1-14)$ & $1.5(1-20)$ & 0.250 \\
\hline Priapism episodes & $4(1-8)$ & $1(1-5)$ & 0.004 \\
\hline Outcome & & & 0.334 \\
\hline Detumescence & 4 & 5 & \\
\hline Persistent erections & 2 & 2 & \\
\hline Recurrent priapism & 11 & 4 & \\
\hline Follow up & $3(0-10)$ & $1(1-14)$ & 0.597 \\
\hline
\end{tabular}

\section{DISCUSSION}

Our study included 28 patients with priapism and the majority were adults who presented at a young age with a mean age at first presentation of 26 years. Most of the patients were from Muscat region $(35.7 \%)$ as it is the capital of Oman. SCD as a risk factor constituted $60.7 \%$ and was the most important underlying cause of priapism. The medical and surgical management done for the patients resulted inthe clinical response (outcome) of: $32.1 \%$ immediate detumescence, $14.3 \%$ persistent priapism, $53.6 \%$ recurrent priapism with the development of the following complications:7\% penile hematoma and, $14.3 \%$ erectile dysfunction.

In the comparison between priapism patients with SCD (60.7\%) and non-SCD (39\%), Patients with SCD in our study were young at first presentation (23 years) and $82.1 \%$ of them were adults. In other studies, priapism was reported amongst $35 \%$ of SCD patients, threequarters of whom, had their first experience before the age of 20, and the mean age of the first occurrence was 15 years. ${ }^{15}$ The high rate of SCD $(60.7 \%)$ as the cause of priapism in our study compared to other studies can be explained by the high prevalence of SCD in Oman $(5.8 \%) .{ }^{9}$ In our study most of the priapism patients with SCD were adults (82.4\%) compared to other studies were the majority were children $(63 \%) .{ }^{16}$ The causes of non-SCD patients in our study were thalassemia, myeloproliferative disorders, infiltrative prostate cancer and drug induced priapism. Penile metastases from prostate cancer were rarely reported in the literature and most commonly diagnosed due to presentation with malignant priapism, usually treated with external beam radiotherapy with poor prognosis. ${ }^{17}$ The most common presentation of priapism in our study was painful erection (78.6\%). However, all SCD patients had painful erections with the median frequency of priapism episodes being significantly higher in SCD than non-SCD patients $(\mathrm{P}=0.004)$, and this can be explained by the pathophysiology of SCD that leads to ischemic type of priapism. Interestingly, all priapism patients from Dakhlyyah region were due to SCD.

Sickle cell disease patients had significantly lower mean $\mathrm{Hb}$ than non-SCD, 8.8 and $11.6(\mathrm{P}=$ 0.001). In contrast, SCD patients had significantly higher mean WBC $(\mathrm{P}=0.011)$, platelets $(\mathrm{P}=0.017), \operatorname{ALT}(\mathrm{P}=0.011)$, bilirubin $(\mathrm{P}=0.003)$ and $\mathrm{LDH}(\mathrm{P}=0.027)$ than non-SCD patients. Inpriapism patients with $\mathrm{SCD}$, the findings of low $\mathrm{Hb}$ with high $\mathrm{WBC}$, platelets, reticulocytes, $\mathrm{MCV}, \mathrm{MCH}$, bilirubin, and $\mathrm{LDH}$ have been associated with increased hemolysis. ${ }^{18,19}$ In addition, recurrent inflammation, leucocyte adhesion, vasculopathy, increased $\mathrm{RBC}$ arginase, free $\mathrm{Hb}$, and reduced NO bioavailability have been suggested as pathophysiological mechanisms for priapism occurrence in SCD. ${ }^{20}$ Since SCD patients had more recurrent episodes of priapism and they had association with certain biochemical factors like low $\mathrm{Hb}$, and high WBC, platelets, ALT, bilirubin, and LDH; it can 
be useful to monitor these parameters at presentation to predict patients who will have frequent priapism episodes and need more stringent follow up. Non the less, further studies with higher number of patients are needed to confirm these predictions.

Stuttering priapism is most commonly described in patients with SCD with an incidence of $64 \%{ }^{21}$ The reported causes of stuttering priapism in adults were idiopathic, medications, neoplasms, and hematological, neurological and metabolic disorders. ${ }^{1}$ The pathophysiology of stuttering priapism is a multifactorial process. The imbalance between normal erection and detumescence have been explained by deficiencies in endothelial nitric oxide (NO) that lead to downregulation of PDE-5 and the inability to regulate cGMP with resulting in disproportionate responses to stimuli. Androgens have been shown to be important regulators of nitric oxide synthase (NOs) and PDE-5 in penile tissue and dihydrotestosterone (DHT) was established to play an important role in promoting erectile function. ${ }^{22}$ Different treatments of recurrent priapism (suturing) have been proposed including: stilboestrol, sildenafil, ephedrine, etilefrine, digoxin, baclofen, terbutaline, ketoconazole, gabapentin, and hormonal therapies. ${ }^{23}$ However, there was a lack of evidence for the benefits or risks of such treatments in sickle cell disease. ${ }^{24,25}$ Recently, dutasteride therapy in patients with stuttering priapism, was shown to be a promising option to reduce the frequency and severity of priapic episodes without significant side effects. ${ }^{26}$ Also, intracorporealh ADSC (human adipose tissuederived stem cells) injection has been shown to limit the fibrosis in a priapismrat model; which was attributed to the potential ofhADSCs to produce various growth factors that could limit TGF $\beta 1$ (Transforming Growth Factor $\beta 1$ ) and collagen production. ${ }^{27}$

\section{CONClusion}

Sickle cell disease is the major risk factor for ischemic priapism and recurrent priapism episodes (stuttering priapism). Patients with priapism are mainly adults who present at young age and suffer from the disease lifelong. Hence monitoring laboratory parameters at presentation such as CBC, LFT, LDH and sickle cell test can help in predicting patients with recurrent priapism who need proper education and a strict follow up to prevent the devastating complications of priapism including pain and erectile dysfunction. The limitations of this study are the low number of patients, limited follow up period and a single center cohort study.The prevalence of priapism in Oman needs to be elucidated by multicenter studies.

\section{Acknowledgments}

We thank the hospital administration for the use of hospital material in this study and the hematology department for taking care of sickle cell patients with priapism.

\section{Advances in Knowledge}

Priapism is a rare disease and studying its causes and the risk factors for recurrent episodes will advance the knowledge that will be of help to prevent devastating complications that lead to poor quality of life like pain and erectile dysfunction.

\section{Application to Patient Care}

Monitoring CBC, LFT, LDH and Sickle cell test in patients with priapism can be used to identify patients at risk of developing stuttering priapism.

\section{REFERENCES}

[1] Salonia A, Eardley I, Giuliano F, et al. European association of urology guidelines on priapism. Eur Urol. 2014;65(2):480-489. doi:10.1016/j.eururo.2013.11.008

[2] Hamre MR, Harmon EP, Kirkpatrick D V., Stern MJ, Humbert JR. Priapism as a complication of sickle cell disease. J Urol. 1991;145(1):1-5.doi:10.1016/S0022-5347(17) 38229-0

[3] Podolej GS, Babcock C. Emergency Department Management Of Priapism. Emerg Med Pract. 2017;19(1):1-16.

[4] Broderick GA, Kadioglu A, Bivalacqua TJ, Ghanem H, Nehra A, Shamloul R. Priapism: Pathogenesis, epidemiology, and management. $J$ Sex Med. 2010;7(1 PART 2):476-500. doi:10.1111/j.1743-6109.2009.01625.x

[5] Shih WV, Wong C. Priapism and hemodialysis: Case report and literature review. ClinNephrol. 2018;90(1):64-70. doi:10.5414/CN109416

[6] Donaldson JF, Rees RW, Steinbrecher HA. Priapism in children: A comprehensive review and clinical guideline. J Pediatr Urol. 2014;10(1):11-24.doi:10.1016/j.jpurol.2013 .07 .024

[7] El-Bahnasawy MS, Dawood A, Farouk A. Low-flow priapism: Risk factors for erectile dysfunction. BJU Int. 2002;89(3):285-290. doi:10.1046/j.1464-4096.2001.01510.x

[8] Bunn HF. Pathogenesis and treatment of sickle cell disease. N Engl J Med. 1997;337(11):762769.doi:10.1056/NEJM199709113371107 
Alkindi S, Al Zadjali S, Al Madhani A, et al. Forecasting hemoglobinopathy burden through neonatal screening in Omani neonates. Hemoglobin. 2010;34(2):135-144. doi:10.3109/ 03630261003677213

[9] Bivalacqua TJ, Musicki B, Kutlu O, Burnett AL. New Insights into the Pathophysiology of Sickle Cell Disease-Associated Priapism. J Sex Med. 2012;9(1):79-87. doi:10.1111/j.17436109.2011.02288.x

[10] Upadhyay J, Shekarriz B, Dhabuwala CB. Penile implant for intractable priapism associated with sickle cell disease. Urology. 1998;51(4):638-639. doi:10.1016/S00904295(97)00704-8

[11] Bartolucci P, Galactéros F. Clinical management of adult sickle-cell disease. CurrOpinHematol. $\quad$ 2012;19(3):149-155.doi: 10.1097/MOH.0b013e328351c35f

[12] Muneer A, Minhas S, Freeman A, Kumar P, Ralph DJ. Investigating the effects of high-dose phenylephrine in the management of prolonged ischaemic priapism. J Sex Med. 2008;5(9): 2152-2159.doi:10.1111/j.1743-6109.2008.00 862.x

[13] Brant WO, Garcia MM, Bella AJ, Chi T, Lue TF. T-Shaped Shunt and Intracavernous Tunneling for Prolonged Ischemic Priapism. $J$ Urol. 2009;181(4):1699-1705. doi:10.1016/j. juro.2008..021

[14] Adeyoju AB, Olujohungbe ABK, Morris J, et al. Priapism in sickle-cell disease; incidence, risk factors and complications - An international multicentre study. BJU Int. 2002;90(9):898-902. doi:10.1046/j.1464-410X. 2002.03022. $\mathrm{x}$

[15] Nelson JH, Winter CC. Priapism: evolution of management in 48 patients in a 22 year series. $J$ Urol. 1977;117(4):455-458.doi:10.1016/ S00 22-5347(17)58497-9

[16] Mansbridge MM, Strahan A, Parker J, Rhee H. PSMA-PET/CT-avid metastatic prostate cancer to the penis. BMJ Case Rep. 2020;13(3). doi:10.1136/bcr-2019-233522

[17] Alkindi S, Almufargi SS, Pathare A. Clinical and laboratory parameters, risk factors predisposing to the development of priapism in sickle cell patients. ExpBiol Med. 2020;245(1): 79-83.doi:10.1177/1535370219 892846
[18] Nolan VG, Wyszynski DF, Farrer LA, Steinberg MH. Hemolysis-associated priapism in sickle cell disease. Blood. 2005;106(9):32643267. doi:10.1182/blood-2005-04-1594

[19] Kato GJ, Hebbel RP, Steinberg MH, Gladwin MT. Vasculopathy in sickle cell disease: Biology, pathophysiology, genetics, translational medicine, and new research directions. In: American Journal of Hematology. Vol 84. Am J Hematol; 2009:618625. doi:10.1002/ajh.21475

[20] Kheirandish P, Chinegwundoh F, Kulkarni S. Treating stuttering priapism. BJU Int. 2011;108(7):1068-1072. doi:10.1111/j.1464410X.2011.10367.x

[21] Lugg JA, Rajfer J, González-Cadavid NF. Dihydrotestosterone is the active androgen in the maintenance of nitric oxide-mediated penile erection in the rat. Endocrinology. 1995;136(4): 1495-1501.doi:10.1210/endo. 136.4.7534702

[22] Abern MR, Levine LA. Ketoconazole and Prednisone to Prevent Recurrent Ischemic Priapism. J Urol. 2009;182(4 SUPPL.):14011406. doi:10.1016/j.juro.2009.06.040

[23] Chinegwundoh FI, Smith S, Anie KA. Treatments for priapism in boys and men with sickle cell disease. Cochrane Database Syst Rev.2020;4(4).doi:10.1002/14651858. CD004 198.pub4

[24] Burnett AL, Anele UA, Trueheart IN, Strouse JJ, Casella JF. Randomized controlled trial of sildenafil for preventing recurrent ischemic priapism in sickle cell disease. Am J Med. 2014;127(7):664-668. doi:10.1016/j.amjmed.2014.03.019

[25] Baker RC, Bergeson RL, Yi YA, Ward EE, Morey AF. Dutasteride in the long-term management of stuttering priapism. TranslAndrol Urol. 2020;9(1):87-92. doi: 10.21037/tau.2019.07.15

[26] Siregar S, Adriansjah R, Sibarani J, Mustafa A. Effect of intracorporeal human adipose-derived stem cells (hADSCs) on corpora cavernosa transforming growth factor $\beta 1$ (TGF $\beta 1$ ) and collagen type $\mathrm{i}$ concentration in wistar rat priapism model. Res Reports Urol. 2020;12:2127. doi:10.2147/RRU.S232303

Citation: Mohamed S. Al-Marhoon , Mohamed S. Al-Masruri. Demography of Priapism: Comparison between Sickle Cell and Non-Sickle Cell Disease Patients.ARC Journal of Urology. 2020; 5(1):3-9. DOI: https://doi.org/ 10.20431/2456-060X.0501002.

Copyright: (c) 2020 Authors. This is an open-access article distributed under the terms of the Creative Commons Attribution License, which permits unrestricted use, distribution, and reproduction in any medium, provided the original author and source are credited. 